\title{
Gymnastics Skill Level and Fitness in Students Selected for Physical Education Programs
}

\author{
Besim Halilaj', Dejan Madić ${ }^{2}$ and Goran Sporiš ${ }^{3}$ \\ 'University of Montenegro, Faculty for Sport and Physical Education \\ 2University of Novi Sad, Faculty of Sport and Physical Education \\ ${ }^{3}$ University of Zagreb, Faculty of Kinesiology
}

\section{Abstract}

The primary purpose of this study was to determine the relationships between fitness tests, and the results in selected gymnastic skills in students enrolled in Physical education teacher education (PETE) program. The secondary purpose of this study was to establish which assessment tests best represent, or correspond, with selected gymnastics skills. A total of 170 male students were recruited from the Faculty of Sport and Physical Education of the University of Priština to participate in the study. The participants were tested for several fitness tests, and performance in selected gymnastic skills. There were significant correlations between the results of fitness tests and performance in gymnastic skills. Significant correlation was found between flexibility, abdominal muscle strength and endurance and performance in gymnastics. Moreover, several fitness tests could serve as significant predictors for performance in several gymnastic skills. The results of this research suggest that, among the students of the Faculty of Sport and Physical Education, abdominal strength and flexibility are a significant predictor for the successful acquisition of the gymnastics program content.

Key words: assessment; correlation; gymnastics; motor abilities; PETE program.

\section{Introduction}

Gymnastics is a sport that consists of several disciplines: Artistic Gymnastics, Rhythmic Gymnastics, Aerobic Gymnastics, Acrobatic Gymnastics and Trampolining. In addition to a great number of young gymnasts participating in gymnastics, the number of male athletes competing at the recreational and collegiate levels is reportedly 
on the rise (Dowdell, 2011). It is well known that flexibility, speed, power, strength, muscular endurance, agility, and balance have all been associated with gymnastics (Sleeper, Kenyon, Elliott, \& Cheng, 2016). However, according to Visscher, Louer, and Elferink-Gemser (2012), it is impossible to determine which characteristics seem to be most important or which characteristics are definitely needed to be good in gymnastics. Nevertheless, an improved ability to accurately measure strength, power, speed, balance, flexibility, and agility may assist in identifying and remediating deficits in the physical performance characteristics needed in gymnastics (Lindner \& Caine, 1990). Some studies have emphasized the crucial importance of possessing a broad level of physical fitness in the athletic development of gymnastics (Di Cagno et al., 2008; Hutchinson, Tremain, Christiansen, \& Beitzel, 1998). Sawczyn (1985) underlined the importance of physical fitness in gymnastics, showing systematically increasing differences over time between gymnasts and non-trained subjects in flexibility, speed, strength, agility and endurance tests.

Gymnastics, as a content of the physical education curriculum, includes a variety of movements which could influence the students' overall specificities (morphofunctional, motor, psychological, musical), since, among other things, the specificity of physical education is the development of psycho-motor abilities (Višnjić, Jovanović, \& Miletić, 2004). As a form of physical exercise it can provide great possibilities of achieving the goals and tasks in physical education. According to Čuljak, Kalinski, Kezić, and Miletić (2014), many studies have dealt with determining the abilities needed for successful performance of gymnastics elements. Moreover, there is great importance in systematically monitoring comprehensive, targeted, and specific indicators of physical fitness during the gymnastics training process. Finally, and most importantly, there is a strong relationship between skill and fitness (Webster et al., 2014), and between motor abilities and development of gymnastics skills (Pehkonen, 2010). However, according to the aforementioned author, the quality of practice and teacher's expertise were the most important for skill progression. Webster et al. (2014) examined the relationship between teacher fitness and movement competence in a series of gymnastics skills. The results showed that gymnastics performance was significantly correlated with muscular strength/endurance after controlling for previous gymnastics experience, which suggests that muscular strength, especially core (abdominal) strength, could be an important factor in the teacher's ability to competently demonstrate certain fundamental skills in gymnastics.

A good level of fitness is very important for gymnastics to structure the technical requirements of exercises on various apparatuses (Mellos, Dallas, Kirialanis, Fiorilli, \& Di Cagno, 2014). The knowledge of fitness status provides teachers the ability to guide correctly the teaching process and therefore leads to better skill progression of students. This study is significant because the standards for PETE state that Physical Education teachers should achieve and maintain a level of fitness consistent with that expected of young learners, and movement competency functions to increase demonstration accuracy when presenting skills to learners. It raises the question if a 
relationship exists between physical education students' fitness and motor skill levels in gymnastics. Therefore, the primary aim of this paper was to examine the relationship between fitness and gymnastic skills among students of the Faculty of Sport and Physical Education. The secondary aim of this study was to establish which assessment tests best represent, or correspond, with the performance of gymnastics skills.

\section{Materials and Methods Participants}

A total of 170 male students were recruited from the Faculty of Sport and Physical Education of the University of Priština to participate in the study. Participant characteristics are shown in Table 1. All participants read and signed an informed consent form approved by the university's Institutional Review Board. Inclusion criteria required the subjects to be male, between 19 and 28 years of age, regularly practicing three to six days per week. Approval for the study was obtained from the Faculty of Sport and Education of the University of Priština. Exclusion criteria included musculoskeletal pathology currently limiting the student's ability to train or compete; a history of, or current systemic illnesses including cardiovascular or pulmonary disease; musculoskeletal disease or rheumatoid arthritis; and a lack of informed assent given by the subject.

Table 1

Descriptive characteristics of the participants. Data are presented by mean $\pm S D$.

\begin{tabular}{cccc}
\hline $\mathrm{N}$ & Age (years) & Body height $(\mathrm{cm})$ & Body weight $(\mathrm{kg})$ \\
\hline 170 & $21.2 \pm 2.3$ & $178.53 \pm 6.730$ & $73.62 \pm 7.35$ \\
\hline
\end{tabular}

\section{Procedure}

On arrival at the testing site, each participant was asked to complete the informed consent form, which described all the assessment procedures to be followed. Testing was administered in university gyms, with identical physical conditions during both testing sessions. Prior to testing, the subjects completed their regular, coach-directed warm-up routines without regard to the requirements of the tests. Given that field-tests comprised of multiple items are often administered in stations each consisting of an individual item, subjects were placed into groups of 5-10 and moved through each of the stations to complete the testing. Data were collected by gymnastics coaches with a minimum of five years of coaching experience, the principal investigator, and another licensed physical therapist with gymnastics experience.

Fitness tests were: arm plate taping (PLT), standing broad jump (SBJ), the 20 meter run, bent arm hang (BAH), grip strength (GS), sit ups, sit and reach (SAR).

\section{Arm Plate Taping}

The test is used to estimate the frequency of movement. The student has fifteen seconds to alternately tap the two plates on the tapping board with his dominant hand, 
while holding the other hand in between the two plates. The result is the number of alternate double hits.

\section{Standing Broad Jump}

The maximum horizontal distance attained, feet together, was measured. This test evaluates lower limb explosive-strength. The broad jump trials are performed along the side of a steel measuring tape, which was fixed to the floor. Subjects begin the broad jump with their toes on a marked line fixed at the 0 -cm mark of the tape. The distance from the rearmost heel strike to the starting line is marked and measured. The best score of the 3 trials was recorded to the nearest centimetre.

\section{The 20 m Run}

The test is used to estimate running speed. The result is the time it takes a student to run a 20-meter distance from a standing start.

\section{Sit and Reach}

The sit-and-reach test is a measure of hamstring flexibility. The participants sit with their feet approximately hip-wide against the testing box. They keep their knees extended, place the right hand over the left, and slowly reach forward as far as they could by sliding their hands along the measuring board.

\section{Grip Strength}

Using a digital Takei TKK 5101 dynamometer (range, 1-100 kg), the maximum grip strength was measured for both hands.

\section{Bent Arm Hang}

This test is applied to test functional strength in arm and shoulder. The participant under-grips the bar and holds the pull-up as long as he can (with the chin above the bar). The result is the time of the hold measured in tenths of second.

\section{Sit-ups for 30 Seconds}

The aim of this test is to define the abdominal strength and muscle endurance. The participant lies on his back with his knees bent and arms crossed on the opposite shoulder. He rises into seated position and returns into starting position. The instructor's assistant holds the participant's feet. The result is the number of correctly executed raises to seated position (no longer than 30 seconds).

The selected gymnastic skills were: straddle vault, round off, backward roll passing through handstand (BRTH), front up-rise on parallel bars (FUPB). The gymnastics skills for this research were fully explained in Madić (2000). The assessment of gymnastic skills was based on the ratings of four experts (gymnastic judges), according to the model (Madić, 2000), on a scale from 1 to 7 , with the following requirements: Score 1 - The student cannot perform the skill, not even with assistance; Score 2 The exercise is carried out with major assistance from the assistant; Score 3 - The 
exercise is carried out with minor assistance from the assistant; Score 4 - The exercise is performed independently with considerable deviations in technique and bad body posture; Score 5 - The exercise is performed independently with minor deviations in technique and with good body posture; Score 6 - The exercise is done with good technique and good body posture, but with smaller amplitudes; Score 7 - The exercise is performed with a large amplitude with excellent technique and good body posture. Judges worked in pairs so that each pair rated three apparatuses. The first pair of judges evaluated exercises on the bar and vault. Another pair of judges evaluated exercises on the floor. It should be noted that every student performed the same skill twice, with an appropriate pause between the performances, and that each pair of judges assessed both performances. Therefore, students got four grades for each skill (two performances). For a simpler processing of the data, the arithmetic mean of judges' marks for each gymnastic skill was calculated separately.

\section{Statistical Analysis}

All variables in Table 2 are shown as mean and SD. The Kolmogorov-Smirnov test was used to confirm the normality. Descriptive and inferential statistics were performed. Pearson's product-moment correlations (r) were used to evaluate relationships between test variables: fitness tests, and performance in selected gymnastic skills. A stepwise multiple regression analysis was conducted to determine which independent variables in fitness tests and specific gymnastic tests were significant predictors of performance in gymnastics. The level of significance was set at $\mathrm{p} \leq 0.05$ for all the tests. SPSS 17.0 software for Windows (SPSS, Inc., Chicago, IL, USA) was used for the statistical analysis.

\section{Results}

The results of fitness and gymnastics skills for all variables are shown in Table 2.

Table 2

Descriptive statistics for the results of fitness and gymnastics skill tests

\begin{tabular}{lccc}
\hline & Mean \pm SD & Minimum & Maximum \\
\hline Plate tapping & $35.21 \pm 4.61$ & 18 & 51 \\
Sit and reach & $29.16 \pm 8.11$ & 20.5 & 48.0 \\
Standing broad jump & $237.46 \pm 16.88$ & 200 & 285 \\
20 meter run & $3.29 \pm 0.169$ & 2.80 & 4.13 \\
Bent arm hang & $54.93 \pm 18.47$ & 11.03 & 106.00 \\
Sit-ups & $19.53 \pm 2.38$ & 13 & 27 \\
Grip strength & $56.68 \pm 8.73$ & 36.40 & 85.10 \\
Straddle vault & $3.62 \pm 1.24$ & 2 & 6 \\
Round off & $3.24 \pm 1.23$ & 1 & 6 \\
BRTH & $3.22 \pm 1.08$ & 2 & 6 \\
FUPB & $3.35 \pm 1.38$ & 1 & 6 \\
\hline
\end{tabular}

BRTH-Backward roll passing through handstand, FUPB- Front up-rise on parallel bars 
Subsequently, a bivariate correlation analysis was carried out between the results obtained from the variables in the fitness tests and the results of performance of gymnastics skills. There were significant correlations between fitness tests and performance in gymnastic skills (Table 3).

Table 3

Correlations between fitness tests and performance in selected gymnastic skills $(N=170)$

\begin{tabular}{lcccccccc}
\hline & \multicolumn{2}{c}{ Vault } & \multicolumn{2}{c}{ Round off } & \multicolumn{2}{c}{ BRTH } & \multicolumn{2}{c}{ FUPB } \\
\hline & $r$ & $p$ & $r$ & $p$ & $r$ & $p$ & $r$ & $p$ \\
\hline PLT & $.169^{*}$ & .026 & $.213^{* *}$ & .005 & $.205^{* *}$ & .007 & .076 & .323 \\
SBJ & $.151^{*}$ & .048 & .127 & .097 & $.221^{* *}$ & .004 & $.269^{* *}$ & .000 \\
Sit-ups & $.215^{* *}$ & .005 & $.246^{* *}$ & .001 & $.232^{* *}$ & .002 & $.227^{* *}$ & .003 \\
20m & .136 & .074 & .088 & .250 & $.154^{*}$ & .044 & .140 & .067 \\
BAH & $.161^{*}$ & .035 & .111 & .149 & $.227^{* *}$ & .003 & $.268^{* *}$ & .000 \\
GS & .167 & .790 & -.065 & .400 & .053 & .490 & -.009 & .908 \\
SAR & $.306^{* *}$ & .000 & $.273^{* *}$ & .000 & $.336^{* *}$ & .000 & $.324^{* *}$ & .000 \\
\hline
\end{tabular}

PLT-Plate tapping, SBJ- Standing broad jump, 20m - the 20 meter run, BAH- bent arm hang, GS- grip strength, SAR-Sit and reach; Vault- Straddle vault, BRTH- Backward roll passing through handstand, FUPB- front up-rise on parallel bars

The Vault was positively correlated with PLT, SBJ, BAH, Sit-ups, SAR and BRTH. However, the Vault showed no correlated with 20m nor GS.

Significant correlations between Round off and fitness tests were found (Table 3). The Round off was positively correlated with PLT, Sit-ups and SAR, but no correlation was found with SBJ, 20m run, BAH and GS. The BRTH was positively correlated with all fitness variables except GS. The FUPB was related with SBJ, Sit-ups, BAH and SAR. No significant correlations were found between gymnastic skills and $20 \mathrm{~m}$ run test, except for BRTH $(\mathrm{p}=0.44)$.

Table 4

Stepwise multiple linear regressions between fitness and performance in gymnastics

\begin{tabular}{lcccc}
\hline Dependent variable & Independent variable & Adjusted R2 & Significance & SEE \\
\hline Vault & SAR & 0.105 & 0.001 & 1.179 \\
\multirow{3}{*}{ Round off } & SAR & & 0.011 & 1.194 \\
& Sit-ups & 0.132 & 0.015 & 1.175 \\
& PLT & & 0.020 & 1.159 \\
BRTH & SAR & & 0.001 & 1.027 \\
& BAH & 0.172 & 0.009 & 1.012 \\
& PLT & & 0.014 & .997 \\
\multirow{2}{*}{ FUPB } & SAR & & 0.005 & 1.308 \\
& SBJ & 0.154 & 0.012 & 1.285 \\
& Sit-ups & & 0.046 & 1.274 \\
\hline
\end{tabular}


Lastly, data about linear regressions (Table 4), which determine the relationship between variables, were obtained to check the linearity established between the independent variables and performance in gymnastic skills. The multiple regression analysis included all independent variables and identified SAR, Sit-ups, PLT, BAH, and SBJ as significant predictors of performance in gymnastic skills. These variables accounted for more than $30 \%$ of the variability in all gymnastic skills.

\section{Discussion}

The primary purpose of this study was to determine the relationships between fitness tests and the results in selected gymnastic skills, and the secondary purpose was to identify assessment tests that best predict, or represent, performance.

Several significant positive correlations were identified between fitness tests and performance variables. Although SAR, Sit-ups, PLT, BAH, and SBJ were best predictors in performance, reliance on these variables could not be recommended because the final adjusted $r$-square was low, which means that our predictors account for around $30 \%$ of the variance in overall satisfaction. This is somewhat disappointing, but fairly normal in social science research.

Sit-ups had significant correlations with all of the results in gymnastic skills. Even though Sit-ups test was used to examine muscle endurance of the trunk, subjects had to use their trunk muscles to stabilize their upper body in an upright position. This means that the core muscles were contracted isometrically throughout the test despite dynamic movements. These similarities in muscle contraction and activation types may have resulted in their significant correlations. Next, significant correlations were identified between flexibility and all gymnastic skills. Nelson, Johnson, and Smith (1983) investigated the relationship between gymnasts' flexibility and strength and varying training intensity levels. The gymnasts at the highest level of training were reported to be the most flexible, weighed less, and demonstrated higher amounts of both functional and absolute strength, especially in the upper body. Faria and Faria (1989) concluded that the top gymnasts possessed greater overall flexibility through the hip region, shoulder girdle, and back.

Živčić-Marković, Sporiš, and Čavar (2011) concluded that there is a disturbingly low level of the prior knowledge of gymnastics, which dictates the views regarding its implementation with primary and secondary school children. Moreover, an important fact that influences the importance of gymnastics in the curriculum is that it is particularly suitable for the adoption of basic movement structures that are stored in the motor base in the form of motor fundamentals necessary for efficient movement and their application in everyday life (Novak, Kovač, \& Čuk, 2008). Accordingly, Tabaković, Ibrahimović, and Tabaković (2013) tried to determine if applied contents of artistic gymnastics program have significant effects of some motor abilities on male students of the Faculty of Sport and Physical Education. They found changes in strength and flexibility and in the area of coordination following the gymnastics program. Gymnastic 
elements are irreplaceable contents that have an overall impact on the anthropological status of children, so they should play a more important role in the physical education curriculum at each level of education, especially in the lower elementary school classes (Delaš Kalinski, Miletić, \& Božanić, 2011). Sands (2000) suggested that a gymnast routinely and repeatedly performs difficult skills, but may not possess the overall physical abilities and fitness levels necessary for prolonged, successful participation in the sport. There is a great annual injury rate in male and female gymnasts (Westermann, Giblin, Vaske, Grosso, \& Wolf, 2015). Using the fitness tests and specific gymnastic testing to identify deficits in sport-specific physical abilities that can be targeted as part of a gymnast's individual training regime may prove useful in injury prevention. Being physically fit has been shown to be an important characteristic of an effective physical education teacher (Gold, Petrella, Angel, Ennis, \& Woolley, 2012; Kamla, Snyder, Tanner, \& Wash, 2012). Moreover, physical education authorities agree that physically fit teachers provide better role models for their students (Gold et al., 2012). Gymnastics has been constantly considered as an area in which PETE students possess limited content knowledge (Sloan, 2007). The abovementioned facts lead us to the conclusion that PETE students with unacceptable fitness levels perform below basic level and may not have a sense of professional obligation to improve on their competence, which was confirmed by our results. This study was limited by several factors. The total number of participants at any level ranged from 18 to 28 . Moreover, the participants were students of the Faculty of Sport and Physical Education, who are engaged in numerous activities throughout their studies. However, the results of this study, the relationships between fitness and gymnastics skills in PETE students warrant further studies.

\section{Conclusions}

In conclusion, there is a significant correlation between flexibility, abdominal muscle strength and endurance and performance in gymnastics. Gymnastics is included in all Physical Education curricula, at each level of education. This study provides initial evidence that fitness is related to students' movement competency. Accordingly, accurate demonstrations in gymnastics are of a great importance in physical education teaching. Moreover, the establishment of a fitness or gymnastics-specific field test, which assesses the physical abilities of students or gymnasts, is a first step in identifying and subsequently improving the physical abilities and content knowledge of physical education students or probably the competitive gymnasts across the world, too. Although this study offers only a glimpse into the link between students' fitness and skills, the results suggest that institutions should think about improving their fitness in order to increase teaching effectiveness. 


\section{References}

Čuljak, Z., Kalinski, S. D., Kezić, A., \& Miletić, Đ. (2014). Influence of fundamental movement skills on basic gymnastics skills acquisition. Science of Gymnastics Journal, 6(2), 73-82.

Delaš Kalinski, S., Miletić, D., \& Božanić, A. (2011). Gender-based progression and acquisition of gymnastic skills in physical education. Croatian Journal of Education, 13(3), 4-24.

Di Cagno A., Baldari C., Battaglia C., Brasili P., Merni F., Piazza, M. et al. (2008). Leaping ability and body composition in rhythmic gymnastics for talent identification. Journal of Sports Medicine and Physical Fitness, 48(3), 341-346.

Dowdell, T. (2011). Is gymnastics a dangerous sport in the Australian club context? Science of Gymnastics Journal, 3(2), 13 - 25.

Faria, I.E., \& Faria, E. W. (1989). Relationship of the anthropometric and physical characteristics of male junior gymnasts to performance. The Journal of Sports Medicine and Physical Fitness, 29(4), 369-378.

Gold, R. R., Petrella, J., Angel, J., Ennis, L. S., \& Woolley, T. W. (2012). The qualities of physical education teachers based upon students' perceptions of physical appearance. Journal of Instructional Psychology, 39(2), 92-104.

Hutchinson, M. R., Tremain, L., Christiansen, J., \& Beitzel, J. (1998). Improving leaping ability in elite rhythmic gymnasts. Medicine and Science in Sports and Exercise, 30(10), 1543-1547. https://doi.org/10.1097/00005768-199810000-00012

Kamla, J., Snyder, B., Tanner, L., \& Wash, P. (2012). Are physical education majors models for fitness? Journal of the Southeastern Regional Association of Teacher Educators, 22(1), 16-22.

Lindner, K. J., \& Caine, D. (1990). Injury predictors among female gymnasts' anthropometric and performance characteristics. In G. P. H. Hermans, \& W. L. Mosterd (Eds.), Sports, Medicine and Health (pp. 136-141). Amsterdam: Excerpta Medica.

Madić, D. (2000). Povezanost antropoloških dimenzija studenata Fizičke kulture sa njihovom uspešnošću vežbanja na spravama [Association of anthropological dimensions with performance in gymnastics among students of physical culture] (Doctoral dissertation). Novi Sad: Fakultet sporta i fizičkog vaspitanja.

Mellos, V., Dallas, G., Kirialanis, P., Fiorilli, G., \& Di Cagno, A. (2014). Comparison between physical conditioning status and improvement in artistic gymnasts and non-athletes peers. Science of Gymnastics Journal, 6(1), 33-43.

Nelson, J. K., Johnson, B. L., \& Smith, G. C. (1983). Physical characteristics, hip flexibility and arm strength of female gymnasts classified by intensity of training across age. The Journal of Sports Medicine and Physical Fitness, 23(1), 95 - 101.

Novak, D., Kovač, M., \& Čuk, I. (2008). Gimnastična abeceda [Gymnastic alphabet]. Ljubljana: Fakulteta za šport Univerze v Ljubljani.

Pehkonen, M. (2010). Quality of the teaching process as an explanatory variable in learning gymnastics skills. Science of Gymnastics Journal, 2(2), 29-40.

Sands, W. A. (2000). Injury prevention in women's gymnastics. Sports Medicine, 30(5), 359-373. https://doi.org/10.2165/00007256-200030050-00004

Sawczyn, S. (1985). Physical development and physical fitness of artistic gymnasts aged 10-15 years [in Polish]. (Doctoral dissertation). Poznań: AWF. 
Sleeper, M. D., Kenyon, L. K. Elliott, J. M., \& Cheng, M. S. (2016). Measuring sport-specific physical abilities in male gymnastics: The men's gymnastics functional measurement tool. International Journal of Sports Physical Therapy, 11(7), 1082-1100.

Sloan, S. (2007). An investigation into the perceived level of personal subject knowledge and competence of a group of pre-service physical education teachers towards the teaching of secondary school gymnastics. European Physical Education Review, 15, 337-364. https://doi. org/10.1177/1356336X07072674

Tabaković, M., Ibrahimović, M., \& Tabaković, A. (2013). Effects of applied contents of artistic gymnastics program on some motor abilities of the faculty of sport and physical education students. Homo Sporticus, 2, 25-28.

Višnjić, D., Jovanović, A., \& Miletić, K. (2004). Teorija i metodika fizičkog vaspitanja [Theory and teaching methodology of physical education]. Beograd: SIA.

Visscher, C., Louer, L., \& Elferink-Gemser, M. T. (2012). The perfect elite gymnast, does he exist? A systematic review. Annals of Research in Sport and Physical Activity, 3, 39-61.https:// doi.org/10.14195/2182-7087 32

Webster, C. A., Webster, L., Cribbs, J., Wellborn, B., Lineberger, B., \& Doan, R. (2014). The relationship between preservice teachers' health-related fitness and movement competency in gymnastics. The Physical Educator, 71(2), 203-217.

Westermann, R. W., Giblin, M., Vaske, A., Grosso, K., \& Wolf, B. R. (2015). Evaluation of Men's and Women's Gymnastics Injuries: A 10-Year Observational Study. Sports Health, 7(2), 161 165. https://doi.org/10.1177/1941738114559705

Živčić-Marković, K., Sporiš, G., \& Čavar, I. (2011). Initial state of motor skills in sports gymnastics among students at Faculty of Kinesiology. Acta Kinesiologica, 5(1), 67-72.

\section{Besim Halilaj}

University of Montenegro, Faculty for Sport and Physical

Education

Džordža Vašingtona bb, Podgorica 81000, Montenegro

besimhalilaj@yahoo.com

\section{Dejan Madić}

University of Novi Sad, Faculty of Sport and Physical Education

Lovćenska 16, Novi Sad 21000, Serbia

dekimadic@gmail.com

\section{Goran Sporiš}

University of Zagreb, Faculty of Kinesiology

Horvaćanski zavoj 15, 10000 Zagreb, Croatia

goran.sporis@kif.hr 


\section{Razina gimnastičkih vještina i tjelesne kondicije kod učenika odabranih za programe tjelesnog odgoja}

\section{Sažetak}

Osnovna svrha ove studije bila je utvrditi odnose izmedu kondicijskih testova $i$ rezultata odabranih gimnastičkih vještina kod studenata odabranih za program obrazovanja učitelja tjelesnog odgoja. Sekundarna svrha te studije bila je utvrditi koji testovi procjene najbolje predstavljaju ili odgovaraju odabranim vještinama gimnastike. Na Fakultetu sporta i tjelesnog odgoja Sveučilišta u Prištini odabrano je ukupno 170 muških studenata koji su sudjelovali u studiji. Sudionici su testirani putem nekoliko kondicijskih testova i kroz izvedbu u odabranim gimnastičkim sposobnostima. Pronađene su značajne korelacije izmedu rezultata kondicijskih testova $i$ izvedbi u gimnastičkim vještinama. Pronađena je značajna povezanost između fleksibilnosti, snage trbušnih mišića i izdržljivosti i izvedbe u gimnastici. Štoviše, nekoliko kondicijskih testova moglo bi poslužiti kao značajan prediktor za izvedbu u nekoliko gimnastičkih vještina. Rezultati ovog istraživanja upućuju na zaključak da su među studentima Fakulteta sporta i tjelesnog odgoja, abdominalna snaga i fleksibilnost značajan prediktor uspješnog savladavanja programskih sadržaja gimnastike.

Ključne riječi: gimnastika; korelacija; motoričke sposobnosti; procjena; program tjelesnog odgoja

\section{Uvod}

Gimnastika je sport koji se sastoji od nekoliko disciplina: sportska gimnastika, ritmička gimnastika, aerobna gimnastika, akrobatska gimnastika i trampolini. Osim velikog broja mladih gimnastičara koji sudjeluju u gimnastici, broj muških sportaša koji se natječu na rekreativnim i sveučilišnim razinama navodno je u porastu (Dowdell, 2011). Poznato je da su fleksibilnost, brzina, snaga, čvrstina, mišićna izdržljivost, agilnost i ravnoteža povezani s gimnastikom (Sleeper, Kenyon, Elliott, i Cheng, 2016). Međutim, prema Visscheru, Louer i Elferink-Gemseru (2012) nemoguće je utvrditi koje karakteristike izgledaju kao najvažnije ili koje 
karakteristike svakako trebaju biti dobre u gimnastici. Ipak, poboljšana sposobnost za točno mjerenje snage, čvrstine, brzine, ravnoteže, fleksibilnosti i agilnosti može pomoći u prepoznavanju i sanaciji deficita u karakteristikama tjelesnog učinka potrebnog za gimnastiku (Lindner i Caine, 1990). Neke studije naglasile su ključnu važnost posjedovanja široke razine tjelesne kondicije $u$ atletskom razvoju gimnastike (Di Cagno i sur., 2008; Hutchinson, Tremain, Christiansen i Beitzel, 1998). Sawczyn (1985) je naglasio važnost tjelesne kondicije u gimnastici, koja sustavno povećava razlike između gimnastičara i nepripremljenih ispitanika s obzirom na fleksibilnost, brzinu, čvrstoću, agilnost i izdržljivost.

Gimnastika, kao sadržaj kurikula tjelesnog odgoja, obuhvaća niz pokreta koji bi mogli utjecati na sveukupne specifičnosti učenika (morfo-funkcionalni, motorički, psihološki, glazbeni), budući da je, između ostalog, specifičnost tjelesnog odgoja razvoj psihomotoričkih sposobnosti (Višnjić, Jovanović i Miletić, 2004). Kao oblik tjelesne vježbe gimnastika može pružiti velike mogućnosti postizanja ciljeva i zadataka u tjelesnom odgoju. Prema Čuljak, Kalinski, Kezić, i Miletić (2014), velik broj studija bavi se određivanjem sposobnosti potrebnih za uspješno izvođenje gimnastičkih elemenata. Štoviše, velika je važnost sustavnog praćenja sveobuhvatnih, ciljanih i specifičnih pokazatelja tjelesne kondicije tijekom treninga gimnastike. Na kraju, i najvažnije, postoji snažna veza između vještine i tjelesne kondicije (Webster i sur., 2014). Osim toga, postoji snažna veza između motoričkih sposobnosti i razvoja vještina gimnastike (Pehkonen, 2010). Međutim, prema spomenutom autoru, kvaliteta prakse i stručnost učitelja bili su najvažniji za poboljšavanje vještina. Webster et al. (2014) ispitali su odnos između tjelesne kondicije učitelja i sposobnosti kretanja u nizu gimnastičkih vještina. Rezultati pokazuju da je gimnastika bila značajno povezana $\mathrm{s}$ mišićnom snagom/izdržljivošću nakon što je kontrolirano i prethodno iskustvo u gimnastici, što upućuje na to da bi mišićna snaga, osobito abdominalna snaga, mogla biti važan čimbenik sposobnosti učitelja da kompetentno demonstriraju određene temeljne vještine $u$ gimnastici.

Dobra razina tjelesne kondicije vrlo je važna za gimnastiku kako bi se strukturirali tehnički zahtjevi vježbanja na različitim spravama (Mellos, Dallas, Kirialanis, Fiorilli, i Di Cagno, 2014). Poznavanje stanja kondicije osigurava nastavnicima sposobnost pravilnog vođenja nastave i time dovodi do boljeg napredovanja u učenju. Ta je studija značajna jer standardi za programe tjelesnog odgoja navode da nastavnici tjelesnog odgoja trebaju postići i održavati razinu kondicije koja je u skladu s onom koja se očekuje od mladih polaznika, a kompetencije u kretanju povećavaju sposobnosti za točnost demonstracije prilikom predstavljanja vještina učenicima. Postavlja se pitanje postoji li veza između kondicije studenata tjelesnog odgoja i motoričkih vještina u gimnastici? Stoga je primarni cilj ovog rada bio ispitati odnos između kondicije i gimnastičkih vještina među studentima Fakulteta sporta i tjelesnog odgoja. Sekundarni cilj ove studije bio je utvrditi koji testovi procjene najbolje predstavljaju ili odgovaraju procjeni gimnastičkih vještina. 


\section{Materijali i metode \\ Sudionici}

Na Fakultetu sporta i tjelesnog odgoja Sveučilišta u Prištini odabrano je ukupno 170 muških studenata koji su sudjelovali u studiji. Karakteristike sudionika prikazane su u tablici 1. Svi sudionici pročitali su i potpisali obrazac pristanka sudjelovanja u studiji koji je odobrio sveučilišni institucijski Odbor. Kriteriji za uključivanje zahtijevali su da ispitanici budu muški, između 19 i 28 godina, koji redovito treniraju tri do šest dana tjedno. Odobrenje za studiju dobiveno je od Fakulteta sporta i obrazovanja Sveučilišta u Prištini. Kriteriji isključenja uključuju muskuloskeletnu patologiju koja trenutačno ograničava sposobnost studenta da trenira ili se natječe; povijest bolesti ili trenutačne bolesti, uključujući kardiovaskularnu ili plućnu bolest; mišićno-koštane bolesti ili reumatoidni artritis i nedostatak pristanka subjekta.

Tablica 1

\section{Postupak}

Po dolasku na mjesto testiranja, od svakog je sudionika zatraženo da popuni obrazac pristanka, koji opisuje sve postupke ocjenjivanja koje treba slijediti. Testiranje je provedeno u sveučilišnim dvoranama, u identičnim tjelesnim uvjetima tijekom oba ispitivanja. Prije ispitivanja ispitanici su izvršili svoje redovito, trenerski vođeno zagrijavanje bez obzira na zahtjeve testova. S obzirom na to da se testovi koji se sastoje od više stavki često provode u stanicama koje se sastoje od pojedinačne stavke, subjekti su bili raspoređeni u skupine od 5 do 10 i kretali su se kroz svaku stanicu kako bi dovršili ispitivanje. Podatke su prikupljali trener gimnastike s najmanje pet godina trenerskog iskustva, glavni istraživač i licencirani fizioterapeut s gimnastičkim iskustvom.

Testovi su bili: taping (PLT), skok s mjesta raširenih nogu (SBJ), trčanje 20 metara, vis savijenim rukama (BAH), jakost hvata (GS), iz ležaja sjed, iz sjeda dohvat (sit and reach) (SAR).

\section{Taping}

Procjenjivanje frekvencije kretanja. Sudionik ima petnaest sekundi da naizmjence dodiruje dvije ploče na ploči za taping s dominantnom rukom, dok drži drugu ruku između dviju ploča. Rezultat je broj alternativnih dvostrukih pogodaka.

\section{Skok s mjesta raširenih nogu}

Izmjerena je maksimalna vodoravna udaljenost koja je postignuta sa skupljenim nogama. Taj test procjenjuje eksplozivnu snagu donjih ekstremiteta. Probe skokova provedene su sa strane čelične mjerne trake koja je bila pričvršćena na pod. Subjekti su započeli skok na nožnim prstima na označenoj liniji fiksiranoj na $0 \mathrm{~cm}$ oznake trake. Označena je i izmjerena udaljenost od početne crte do kraja pete nakon doskoka. Zabilježen je najbolji rezultat od tri pokušaja. 


\section{Trčanje na 20 metara}

Za procjenu brzine trčanja. Rezultat je vrijeme koje studentu treba da bi pretrčao udaljenost od 20 metara od startne linije.

\section{Iz sjeda dohvat (Sit and Reach)}

Test Iz sjeda dohvat bio je mjera fleksibilnosti tetiva koljena. Sudionici su sjedili stopalima naslonjenima na testnu kutiju raširenima otprilike u širini kukova. Držali su ispružena koljena i položili desnu ruku preko lijeve i polako se dizali prema naprijed što je dalje moguće, klizeći rukama duž mjerne ploče.

\section{Jakost hvata}

S pomoću digitalnog dynamiometra Takei TKK 5101 (raspon, 1-100 kg) mjerena je maksimalna čvrstoća hvata za obje ruke.

\section{Vis savijenim rukama}

$\mathrm{Za}$ ispitivanje funkcionalne snage ruku i ramena. Sudionik pothvatom drži preču te drži tijelo u zgibu koliko god može (s bradom iznad preče). Rezultat je vrijeme držanja izmjereno u desetinkama sekunde.

\section{Iz ležanja sjed za 30 sekundi}

Cilj ovog testa je definiranje trbušne snage i izdržljivosti mišića trupa. Sudionik leži na leđima sa savijenim koljenima i rukama prekriženim na suprotnom ramenu. Ustaje u sjedeći položaj i vraća se u početni položaj. Pomoćnik instruktora drži ispitanikova stopala. Rezultat je broj ispravno izvršenih podizanja u sjedeći položaj (ne duže od 30 sekundi).

Odabrane gimnastičke vještine bile su: preskok raširenim nogama, rondat, kolut unatrag kroz stoj na rukama (BRTH), uzmah na ručama (FUPB). Gimnastičke vještine za ovo istraživanje u potpunosti su objašnjene u Madić (2000). Izvedbu gimnastičkih vještina ocjenjivalo je ocjenama četvero stručnjaka (gimnastički suci) prema modelu (Madić, 2000), u mjerilu od 1 do 7, sa sljedećim zahtjevima: Ocjena 1 Student ne može izvoditi vještinu, čak ni uz pomoć; Rezultat 2 - Vježba je provedena uz veliku pomoć asistenta; Ocjena 3 - Vježba je provedena uz malu pomoć asistenta; Ocjena 4 - Vježba je izvedena neovisno, uz znatna odstupanja u tehnici i loš položaj tijela; Ocjena 5 - Vježba je obavljena neovisno s manjim odstupanjima u tehnici i dobrom držanju tijela; Ocjena 6 - Vježba je obavljena dobrom tehnikom i dobrim držanjem tijela, ali s manjim amplitudama; Ocjena 7 - Vježba je izvedena s velikom amplitudom s izvrsnom tehnikom i dobrim držanjem tijela.

Svaki par sudaca procjenjivao je rad na tri sprave. Prvi par sudaca procjenjivao je vježbe na ručama i preči. Drugi par sudaca procjenjivao je vježbe na parteru. Valja napomenuti da je svaki student dva puta izvodio istu vježbu, uz odgovarajuću pauzu između izvedbi i da je svaki par sudaca ocjenjivao oba nastupa. Stoga je za svaku 
vještinu (dva nastupa) student dobio četiri ocjene. Za jednostavniju obradu podataka izračunata je aritmetička sredina ocjene sudaca za svaku gimnastičku vještinu.

\section{Statistička analiza}

Sve varijable u tablici 2 prikazane su kao srednja vrijednost i SD. KolmogorovSmirnov test koristio se za potvrdu normalnosti. Opisane su deskriptivne i inferencijalne statistike. Pearsonova korelacija produkta-trenutka (r) koristila se za procjenu odnosa između testnih varijabli: kondicijskih testova i performansi u odabranim gimnastičkim vještinama. Provedena je postupna višestruka regresijska analiza kako bi se utvrdilo koje su nezavisne varijable u testovima kondicije i specifičnim gimnastičkim testovima bili znatni prediktori izvedbe gimnastike. Razina značenja bila je postavljena na $p \leq 0,05$ za sva ispitivanja. SPSS 17.0 softver za Windows (SPSS, Inc., Chicago, IL, USA) koristio se za statističku analizu.

\section{Rezultati}

Rezultati kondicije i gimnastičkih vještina za sve varijable prikazani su u tablici 2. Tablica 2

PLT-Tap, SBJ - skok s mjesta raširenih nogu, $20 \mathrm{~m}$ - trčanje na $20 \mathrm{~m}$, BAH-vis savijenim rukama, GS - jakost hvata, SAR - iz sjeda dohvat (Sit and reach); Vault - preskok raširenim nogama, BRTH - kolut unatrag kroz stoj na rukama, FUPB uzmah na ručama

Nakon toga je provedena bivarijantna korelacijska analiza između rezultata dobivenih od varijabli u kondicijskim testovima i rezultata izvođenja gimnastičkih vještina. Bilo je značajnih korelacija između kondicijskih testova i performansi u gimnastičkim vještinama (Tablica 3). Vault je bio pozitivno povezan s PLT, SBJ, BAH, Sit ups, SAR i HST. Međutim, Vault nije pokazao korelaciju s $20 \mathrm{~m}$ i GS.

Utvrđene su značajne korelacije između rondata i kondicijskih testova (Tablica 3). Rondat je pozitivno povezan s PLT, iz ležanja sjedom i SAR, ali nema korelaciju s SBJ, trčanjem na $20 \mathrm{~m}$, BAH i GS. BRTH je bio pozitivno povezan sa svim kondicijskim varijablama osim GS. FUPB je bio povezan s SBJ, iz ležanja sjedom, BAH i SAR. Nije bilo značajnih korelacija između gimnastičkih vještina i testova trčanja na $20 \mathrm{~m}$, osim za BRTH $(\mathrm{p}=0,44)$.

\section{Tablica 3}

Na kraju su podaci o linearnim regresijama (Tablica 4), koji određuju odnos između varijabli, dobiveni kako bi se provjerila linearnost uspostavljena između nezavisnih varijabli i performansi u gimnastičkim vještinama. Višestruka regresijska analiza obuhvatila je sve nezavisne varijable i identificirala SAR, iz ležanja sjed, PLT, BAH i SBJ kao značajne prediktore izvedbe gimnastičkih vještina. Te varijable činile su više od $30 \%$ varijabilnosti u svim gimnastičkim sposobnostima.

Tablica 4 


\section{Rasprava}

Primarna svrha ove studije bila je utvrditi odnose između kondicijskih testova i rezultate odabranih gimnastičkih vještina, a sekundarna svrha bila je identificirati testove procjene koji najbolje predviđaju ili predstavljaju performanse.

Utvrđeno je nekoliko značajnih pozitivnih korelacija između kondicijskih testova i varijabli izvedbe. Iako su SAR, iz ležanja sjed, PLT, BAH i SBJ bili najbolji prediktori u izvedbi, oslanjanje na te varijable nije se moglo preporučiti jer je konačni prilagođeni r-kvadrat bio nizak, što znači da naši prediktori čine oko $30 \%$ varijance ukupne uspješnosti. To je pomalo razočaravajuće, ali prilično normalno $u$ istraživanju u društvenim znanostima.

Iz ležanja sjed imao je značajne korelacije sa svim rezultatima gimnastičkih vještina. Iako su se sjedovi iz ležanja koristilii za ispitivanje izdržljivosti trbušnih mišića, subjekti su se morali koristiti mišićima trupa kako bi stabilizirali gornji dio tijela u uspravnom položaju. To znači da su mišići gornjeg dijela trupa bili izometrijski kontrahirani tijekom testa, unatoč dinamičnim pokretima. Te sličnosti u kontrakciji mišića i tipovima aktivacije mogu rezultirati njihovim značajnim korelacijama. Zatim su identificirane značajne korelacije između fleksibilnosti i svih gimnastičkih vještina. Nelson, Johnson, i Smith (1983) istražili su odnos između fleksibilnosti i snage gimnastičara i različitih razina intenziteta treninga. Gimnastičari na najvišoj razini treninga bili su najfleksibilniji, imali manju težinu i pokazali veću razinu funkcionalne i apsolutne snage, posebno u gornjem dijelu tijela. Faria i Faria (1989) zaključili su da su vrhunski gimnastičari imali veću fleksibilnost kroz područje kuka, ramena i leđa.

Živčić-Marković, Sporiš i Cavar (2011) zaključili su da postoji izuzetno niska razina prethodnog znanja gimnastike, što diktira način razmišljanja o njezinoj primjeni u osnovnoj i srednjoj školi. Štoviše, važna činjenica koja utječe na važnost gimnastike u kurikulu jest da je osobito prikladna za usvajanje osnovnih struktura kretanja pohranjenih u motoričkoj bazi u obliku motoričkih osnova nužnih za učinkovito kretanje i primjenu u svakodnevnom životu (Novak, Kovač i Cuk, 2008). U skladu s tim Tabaković, Ibrahimović, i Tabaković (2013) pokušavaju utvrditi imaju li primijenjeni sadržaji sportske gimnastike značajne učinke na neke motoričke sposobnosti kod muških studenata Fakulteta sporta i tjelesnog odgoja. Navedeni autori našli su promjene u snazi i fleksibilnosti, kao i na području koordinacije nakon gimnastike. Gimnastički elementi nezamjenjivi su sadržaji koji imaju ukupan utjecaj na antropološki status djece, pa bi oni trebali imati važniju ulogu u programu tjelesnog odgoja na svakoj razini obrazovanja, posebno u nižim osnovnim školama (Delas Kalinski, Miletić, i Bozanić, 2011). Sands (2000) je sugerirao da gimnastičar rutinski i opetovano izvodi teške vještine, ali ne mora imati sveukupne fizičke sposobnosti i razine kondicije potrebne za dugotrajno i uspješno sudjelovanje u sportu. Postoji velika godišnja stopa ozljeda kod muških i ženskih gimnastičara (Westermann, Giblin, Vaske, Grosso, i Wolf, 2015). Primjena kondicijskih testova i specifičnih gimnastičkih 
testova za prepoznavanje nedostataka u specifičnim sportskim fizičkim sposobnostima koje se mogu usmjeriti kao dio individualnog režima treninga gimnastičara može se pokazati korisnim u prevenciji ozljeda. Pokazalo se da je biti fizički sposoban važno obilježje učinkovitog učitelja tjelesnog odgoja (Zlato, Petrella, Angel, Ennis, i Woolley, 2012; Kamla, Snyder, Tanner i Wash, 2012). Štoviše, autoriteti u tjelesnom odgoju slažu se da fizički sposobni nastavnici pružaju bolji primjer svojim učenicima (Gold i sur., 2012). Gimnastika se stalno razmatra kao područje u kojem studenti tjelesne i zdravstvene kulture posjeduju ograničeno znanje o sadržaju (Sloan, 2007). Navedene činjenice vode nas do zaključka da je izvedba studenata s neprihvatljivim razinama kondicije ispod osnovne razine i da nemaju osjećaj profesionalne obaveze za poboljšanje svojih kompetencija, što je potvrđeno našim rezultatima. Ova je studija bila ograničena na nekoliko čimbenika. Ukupan broj sudionika na bilo kojoj razini bio je od 18 do 28. Osim toga, sudionici su bili i studenti Fakulteta sporta i tjelesnog odgoja koji se bave brojnim aktivnostima tijekom studija. Međutim, rezultati ove studije i odnosi između kondicije i gimnastičkih vještina kod studenata tjelesnog odgoja jamče daljnje studije.

\section{Zaključci}

Zaključno, postoji značajna korelacija između fleksibilnosti, snage trbušnih mišića, izdržljivosti i performansi u gimnastici. Gimnastika je uključena u sve kurikule tjelesnog odgoja, na svakoj razini obrazovanja. Ova studija pruža početne dokaze da je kondicija vezana uz kompetenciju kretanja studenata. Prema tome, točne demonstracije u gimnastici imaju veliku važnost u poučavanju tjelesnog odgoja. Štoviše, uspostava terenskog testa specifičnog za kondiciju ili gimnastiku, koja procjenjuje fizičke sposobnosti učenika ili gimnastičara, prvi je korak u prepoznavanju i naknadnom poboljšanju tjelesnih sposobnosti i znanja o sadržaju tjelesnog odgoja ili vjerojatno natjecateljskih gimnastičara diljem svijeta. Iako ovo istraživanje nudi samo kratak uvid u vezu između kondicije i vještina studenata, rezultati sugeriraju da bi institucije trebale razmisliti o poboljšanju njihovih sposobnosti kako bi povećale učinkovitost učenja. 